\title{
Selected aspects of the health condition of hospitalised soldiers after military action and the manifestation of externalising anger Wybrane zagadnienia dotyczące stanu zdrowia hospitalizowanych żotnierzy po akcjach zbrojnych i przejawy eksternalizacji gniewu
}

\author{
Dorota E. Ortenburger ${ }^{1}$, Jacek Wąsikㄹ, Anatolii Tsos¹, Olga Andrijchuk², Natalia Bielikowa², Svitlana Indyka ${ }^{2}$ \\ ${ }^{1}$ Faculty of Health Sciences, Jan Dlugosz University, Czestochowa, Poland \\ Head of the Department: Prof. Wiesław Pilis PhD \\ ${ }^{2}$ Faculty of Physical Culture, Sport and Health, Lesya Ukrainka Eastern European National University, Lutsk, Ukraine \\ Head of the Department: Dr Vasyl Pantik

Key words: externalising anger, blood pressure, hospitalisation, participants of defensive military actions.

Słowa kluczowe: ekspresja gniewu, ciśnienie krwi, hospitalizacja, uczestnicy obronnych działań wojskowych.

\begin{abstract}
Introduction: Participation in defensive war actions is connected with the necessity of dealing with different difficult mental and health consequences.

Aim of the research: To obtain knowledge concerning typical manifestations of externalising anger in everyday situations by the hospitalised participants of antiterrorist operations, who suffered from posttraumatic stress and whose health worsened.

Material and methods: The research covered 35 hospitalised participants of military action during antiterrorist operations (age: $34.61 \pm 9.23$ years; range: $21-56$ years) in hospitals in Lutsk. The data were obtained with the application of the questionnaire within health psychology, the Anger Expression Scale, and data from the existing documentation.

Results: An image composed of many symptoms was more frequent than a single symptom, which makes us think that we can talk about the appearance of the phenomenon of multiple morbidities in the case of the participants of military actions. There is a slight interdependency between the value of an index of the registered systolic blood pressure of the hospitalised participants of military action and the tendency to express anger $(r=0.41)$. The value of the correlation index between the willingness to act in retaliation and the registered blood pressure was $r=0.58(p<0.05)$. The value of the index of the summary level of externalised anger revealed in typical situations was $24.37 \pm 6.33$ (scores in the scale 10-50). Partial manifestations of externalising anger included raising one's voice as a reaction to shouting $3.06 \pm 1.08$, anger caused by waiting 2.97 \pm 1.22 , and revengeful behaviours $2.80 \pm 1.05$ (scores in the scale 1-5).

Conclusions: An image composed of many symptoms more frequent than a single symptom in the case of the participants of military actions. The diagnosis should, if possible, also cover the nature of social support because the experienced trauma may also concern the closest environment of the participant/participants of antiterrorist actions.
\end{abstract}

\section{Streszczenie}

Wprowadzenie: Udział w obronnych działaniach wojennych wiąże się z koniecznością radzenia sobie z trudnymi konsekwencjami psychicznymi i zdrowotnymi.

Cel pracy: Uzyskanie wiedzy dotyczącej typowych przejawów uzewnętrzniania gniewu w codziennych sytuacjach przez hospitalizowanych uczestników operacji antyterrorystycznych, którzy cierpieli na stres pourazowy, a których zdrowie się pogorszyło.

Materiał i metody: W badaniu wzięło udział 35 hospitalizowanych uczestników obronnych działań bojowych prowadzonych podczas operacji antyterrorystycznych (wiek: 34,61 $\pm 9,23$ roku; przedział wieku: 21-56 lat) w szpitalach w Łucku. Dane uzyskano przy użyciu kwestionariusza stosowanego w psychologii zdrowia, Skali wyrażania gniewu oraz z istniejącej dokumentacji.

Wyniki: Stwierdzono niewielką współzależność między wartością wskaźnika zarejestrowanego skurczowego ciśnienia krwi hospitalizowanych uczestników obronnej akcji bojowej a tendencją do wyrażania gniewu $(r=0,41)$. Wartość wskaźnika korelacji między gotowością do działania odwetowego a zarejestrowaną wartością ciśnienia krwi wynosiła $r=0,58$ $(p<0,05)$. Wartość obliczonego wskaźnika sumarycznego poziomu uzewnętrznianego gniewu w typowych sytuacjach wynosiła 24,37 $\pm 6,33$ (punktów w skali: 10-50). Cząstkowe przejawy uzewnętrznianego gniewu obejmowały: podniesienie 
głosu w reakcji na krzyk $-3,06 \pm 1,08$, złość spowodowaną oczekiwaniem $-2,97 \pm 1,22$, zachowania odwetowe $-2,80 \pm 1,05$ (punkty w skali 1-5).

Wnioski: Obraz złożony z wielu objawów był częstszy niż jeden, pojedynczy objaw chorobowy, co powoduje, że możemy mówić o pojawieniu się zjawiska wielochorobowości w przypadku uczestników działań wojskowych. Diagnoza powinna obejmować, jeśli jest to możliwe, również charakter istniejącego wsparcia społecznego, ponieważ doświadczenie traumy może dotyczyć również najbliższego otoczenia uczestnika lub uczestników działań antyterrorystycznych.

\section{Introduction}

Despite the tragic experiences that have taken place over the years, humanity still cannot escape wars [1]. Participation in defensive war actions is connected with the necessity of dealing with different consequences, including endangering the health and lives of people. The experiences connected with it make a challenge test for the human psyche.

The effect of this is, among others, an increase of anger, which is primarily a reaction to trauma or fear [2]. Tension and excitement increase of the level of aggression and cause changes in physiological reactions (e.g. blood pressure, pulse, blood sugar metabolic changes) [3]. During military actions anger increases the readiness to act; however, the behaviours caused by it can vary in character. As an instrument of aggression, it may be revealed in an immediate attack directed at the opponent, although in very special situations it can trigger aggressive behaviour towards closest relatives and a tendency for autoaggression [1].

Experiencing anger chronically may be an obstacle in rehabilitation. In such cases resistance and unwillingness to use psychological therapy may appear. An additional problem is the fact that, among the accompanying disorders, overuse of psychoactive substances and depression are listed [4].

The participation of military and antiterrorist actions is connected with the risk of experiencing posttraumatic encephalopathy. It may be chronic, often with the tendency of an increase of neuropathological and clinical symptoms. The consequences of it may be, among others, headaches, sleeping disorders, the disappearance of previous interests, and increased irritability [5].

The development of techniques for researching the brain has contributed to knowledge concerning complicated connections between emotions and memory. It is said that there is a phenomenon of "emotion memory". At present, it is assumed that an amygdaloid body, which is one of the most important structures of the limbic system, is responsible for it. In an experimental way it was proved that an amygdaloid body stimulation causes anger and results in acts of fury [6]. An additional destructor may lie in the changes in perceiving one's own injured (temporarily or permanently) body.

The problems that the participants of military and antiterrorist action have to deal with concern the physical and psychical sphere. From the perspective of a holistic paradigm of health, regaining health re- sults from the mutually dependent multidimensional aspects of human functioning, i.e. biological, psychological, social, and spiritual. The system approach to recovery or, at least, partial health improvement makes us think in the categories of the processes directed towards regaining the constantly impaired balance in each of the aspects.

Help provided for such people is connected with immediate lowering of fear and other negative emotions and maintaining an adequate self-assessment [2]. It is important to recognise the typical symptoms of expressing anger, irritation, aggression, etc. These are, among others: willingness to hit another person under the influence of frustration, shouting as reaction to shouting, strong anger while waiting, and very often raising one's voice caused by anger. We know that aggressive behaviours are most frequently revealed in special conditions, e.g. emotional excitement, or discomfort connected with bad conditions $[7,8]$. The obtained knowledge can be used in order to prepare a programme of psychosocial disorder prevention.

\section{Aim of the research}

That is why the aim of the research is to gain knowledge concerning the manifestations of externalising anger in common everyday situations by hospitalised soldiers, taking part in war conflict, who suffered from posttraumatic stress and health impairment.

\section{Material and methods}

\section{Subject}

The research covered 35 hospitalised participants (age: $34.61 \pm 9.23$ years; range: $21-56$ years) of antiterrorist operations (ATO) the aim of which was to break separatists' military groups and remove self-appointed peoples' republics within the territory of Ukraine. The causes of hospitalisation in $76 \%$ of cases were wounds in the ATO area, and in 44\% deterioration of chronic diseases or primary pathological changes. These patients were not covered by professional psychological help. The exclusion criteria included incomplete questionnaire completion. The research was conducted in the Volyn Regional Hospital of War Veterans.

\section{Protocol}

The measurement was performed with the use of the standardised questionnaire of health psychology 
Table 1. Percentage participation of disorders, injuries, and illnesses in a group of hospitalised soldiers

\begin{tabular}{|lc|}
\hline Diagnosis & $\begin{array}{c}\text { Percentage } \\
\text { share }\end{array}$ \\
Spine osteochondrosis in lower back & 37.14 \\
Asthenic syndrome & 22.85 \\
Injuries during fighting, shooting & 22.85 \\
Traumatic brain injuries, & 17.14 \\
encephalopathies & \\
Gastroesophageal reflux disease & 14.28 \\
Pancreatitis. Hepatitis & 11.42 \\
Protrusion of spinal discs & 11.42 \\
Nettle-rash & 11.42 \\
Peripheral nerves injuries. & 5.71 \\
Polyradiculopathies & \\
Retinal angiopathy & 5.71 \\
Clavicle fracture & 2.58 \\
Blood hypertension & 2.85 \\
Vegetative neurosis & 2.8 \\
\hline
\end{tabular}

and the Anger Expression Scale. The reliability available by estimating connection compatibility and absolute application conformity rates range from 0.73 to 0.83 for outward-directed anger and $0.67 \alpha$. The Anger Expression Scale is a Likert-type scale designed to assess the ways in which individuals express their anger $[9,10]$.

Complementary information concerning the examined persons, including patients' health condition, was obtained from medical documentation and oral relation of the persons conducting this research.

\section{Ethics}

The research includes human data, and was performed in accordance with the Declaration of Helsinki and approved by the Lesya Ukrainka Eastern European National University, Lutsk, Ukraine Bioethics Commission (no. 2/2018). Before interviews, the nature and the purpose of the study were explained, and full confidentiality was assured to all participants. All participants were informed about their right not to participate in the study and gave their oral consent before the study.

\section{Statistical analysis}

In the conducted research, for all registered indexes the median (SR), variance (SS), and standard deviation (SD) were established. The correlation between selected indexes was indicated. Data distributions were tested for normality. Data were statistically analysed using the Pearson correlation coefficient. The statistical validity was assumed at the level of $p<0.05$. All calculations were performed with the use of Statistica 12.00.

\section{Results}

The conducted research allowed us to obtain empirical data within the percentage participation of disorders, injuries, and illnesses in a group of hospitalised participants of military action during ATO. Table 1 contains the percentage participation of disorders, injuries, and illnesses in a group of hospitalised soldiers. The most common recognition in the examined group is osteochondrosis in the lower back, asthenic syndrome, injuries from fighting, shooting, traumatic brain injuries, and encephalopathies. The least frequent are clavicle fracture and vegetative neurosis.

The findings of other authors suggest potentially important links among central nervous system regulation of emotions, haemodynamic processes, and hypertension development. Persons with elevated blood pressure (BP) show dampened emotional responses to affect-laden stimuli [11]. Table 2 includes systolic and diastolic blood pressure of 35 hospitalised participants of ATO.

Optimal functioning improvement, considering the emotional individual context of each patient, is a common objective of the interdisciplinary therapeutic interaction [8]. Because anger is a very important problem for the health of each individual, the results obtained in the study group are presented. For this reason, the results of the anger tests of the surveyed users are presented. Figure 1 illustrates the obtained correlation coefficient between systolic blood pressure in the chosen partial symptoms of externalised anger. The correlation coefficient between systolic blood pressure and venting anger (important particular manifestation of externalised anger) was $r=0.58(p<0.05)$.

Table 2. Systolic and diastolic blood pressure of hospitalised patients in the examined group

\begin{tabular}{|lcccccc|}
\hline Pressure & SR & Median & SD & Range & $\begin{array}{c}\text { Lower } \\
\text { quantile }\end{array}$ & $\begin{array}{c}\text { Upper } \\
\text { quantile }\end{array}$ \\
Systolic & 85.74 & 80 & 12.44 & $60-120$ & 80 & 90 \\
Diastolic & 131.62 & 130 & 16.59 & $100-180$ & 120 & 140 \\
\hline
\end{tabular}


Graphic illustration of descriptive characteristics of particular manifestations of externalised anger of soldiers is shown in the Figure 1. The descriptive analysis of the results relating to anger show that in the examined group the value of the index of the average level of anger (externalised) is $24.37 \pm 6.33$ (range: 10-50).

The acquired results relating to anger felt revealed which form prevailed among the hospitalised soldiers: raising voice as reaction to shouting. The value of the indicator of this manifestation on anger reached an average of $3.06 \pm 1.08$, whereas revengeful anger behaviours reached a lower average value of $2.80 \pm 1.05$ (1-5 scale) (Figure 1). Research indicates that negative long-term emotions (like anger) are on the one hand a worse frame of mind, while on the other hand have potential distant health consequences. Therefore, the next of our results relate to the correlation of anger and blood pressure. Figure 2 illustrates the obtained correlation coefficient between systolic blood pressure in the chosen partial symptoms of externalised anger. The correlation coefficient between systolic blood pressure and venting anger (important particular manifestation of externalised anger) was $r=0.58$ $(p<0.05)$.

\section{Discussion}

In the analysed group of hospitalised soldiers, in accordance with the diagnosis given in the hospital, osteochondrosis was very frequently diagnosed. The most common recognition in the examined group was osteochondrosis in the lower back (37.14\%), the next reason was asthenic syndrome $(22.85 \%)$. The next reasons were: injuries during fighting, shootinging $(22.85 \%)$, traumatic brain injuries, and encephalopathies (17.14\%) (Table 1). The least frequent were clavicle fracture $(2.58 \%)$ and vegetative neurosis $(2.8 \%)$. In the examined group the value of the index of average level of anger (externalised) was 24.37 \pm 6.33 (range: $10-50$ ). Partial manifestations of externalising anger, such as raising one's voice as a reaction to shouting $3.057 \pm 1.08$, anger caused by waiting $2.97 \pm 1.22$, revengeful behaviours $2.80 \pm 1.05$ (range: 1-5), and general anger index (range: 10-50), do not differ significantly from the results of other researchers [9].

Among the examined persons, we can notice some similarity, based on the fact that they all took part in military actions and suffered injuries or their health condition worsened to such an extent that hospitalisation was required. In this group we can indicate patients for whom it was not their first stay. Thus, they might have had hospital experiences including ones connected with injury. In their case, a confrontation with current stressor and traces of the past take place. In light of the literature, it means confrontation with renewed memories [12]. An infinite number of

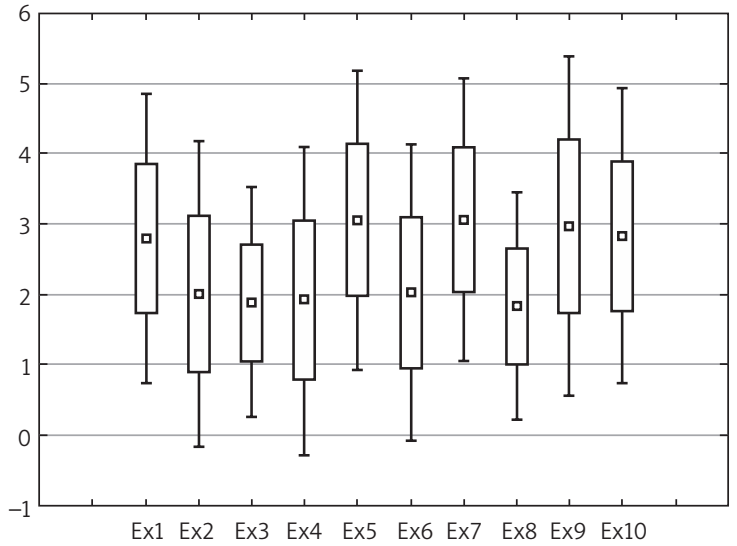

Figure 1. Graphic illustration of descriptive characteristics of particular manifestations of externalised anger (scores on a 1-5 scale), in which: Ex1 - venting anger at the person who was the reason for the nervousness, Ex2 - paying back "grievance for grievance", Ex3 - showing anger, Ex4 - frequent revenge, Ex5 - verbalisation of anger, Ex6 - Willingness to hit another person under the influence of frustration, Ex7 - shouting as reaction to shouting, Ex8 - showing anger, Ex9 - anger while waiting, Ex10 - raising voice caused by anger

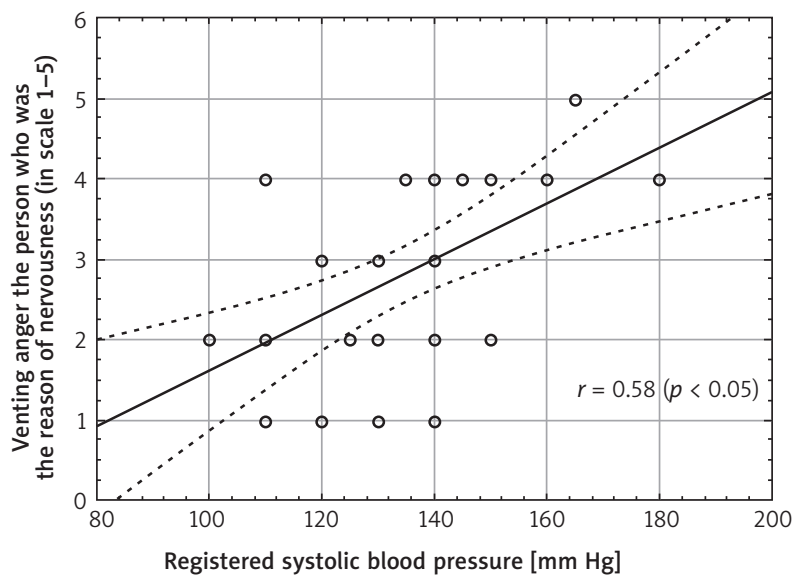

Figure 2. Graphic illustration of correlation between registered systolic blood pressure and particular manifestation of externalised anger (venting anger) $r=0.58(p<0.05)$

memory configurations, which are emotional, creates seemingly accidental sets of associations that are experienced as a condition of subjective awareness. According to this theory, two sets of memories are kept in the associated set, and it causes injuries overlap each other. Such a scenario is particularly frequently observed in the case of soldiers, medical staff, and first aid employees [2].

The accumulation of current and past injuries can have consequences such as that the persons who have participated in the military actions react to many 
situations, as if a trigger mechanism worked in their case, which opens the inflow of unpleasant, automatic flooding thoughts concerning earlier experiences, such as mutilation, fear, and imagining death and dying [13]. The experiences of the soldiers may lead to a crisis: behaviour disorganisation, psychosomatic, and psychopathological disorders [14].

The value of the index of correlation between the registered systolic blood pressure in patients and manifestations of anger revealed tendencies to revengeful behaviour at $r=0.41(p<0.05)$. On the basis of these studies, it can be rather cautiously confirmed that there is a correlation between manifestations of anger and the value of blood pressure. It was also noted that the value of the correlation index between the willingness to act in retaliation and the registered blood pressure was $r=0.58$ (Figure 2).

Following the interpretation of other researchers [11], the results suggest important connections. Other examined manifestations of anger did not reveal interchangeability with systolic or diastolic pressure.

In the case of patients with the highest $25 \%$ of results in the scale of externalising anger (range: 10-50), there are hospitalised persons with the recognition of: osteochondrosis in the lower back, shooting, posttraumatic arthrosis, traumatic brain damage, concussion, tension stenocardia, disc protrusions, and others. In the group of patients whose results in the scale of externalising anger are located in the group of lowest $25 \%$ of results were: post-traumatic encephalopathy, hemiparesis, injuries of right arm elbow, asthenic syndrome, injury of cervical spine $\mathrm{C} 4-\mathrm{C} 7$, sciatic neuralgia with lumbosacral pain, spine osteochondrosis in the lower back, and others (Table 2).

In both groups, based on the level of externalising anger, there were patients who experienced injuries of the structure of the central nervous system (Table 2). The patients of both groups reported problems concerning the musculoskeletal system.

Based on the conducted research, we can say that in the case of hospitalised soldiers it is more frequent that there are many symptoms rather than a single symptom. The appearance of asthenic syndrome, sleeping disorders, or pain ailments of different parts of the spine means potential burden for the immunological system [15]. At the same time, it has a longterm meaning for health and well-being [16].

Other studies addressing this problem have found that the causes of hospitalisation in $56 \%$ of cases were wounds in the ATO area, and in 44\% - deterioration of chronic diseases or primary pathological changes. According to local dermographism, it has been established that more than two thirds of hospitalised participants of the ATO due to the vegetative «passport» are sympathologists and only one third - vagotonics. The finding presents the current subject, which may concern increasingly often soldiers in military ac- tions of different countries. Soldiers' health, not only physical but also mental, is exposed to the number of factors during dangerous military actions. It can have a negative impact on their future lives $[8,9,17]$.

Based on the obtained data, we can talk about a diversified level of manifested anger in connection with the medical recognition and health condition. A small research group may have an impact on it. It may also mean that inside a person there are potential possibilities that allow for some degree of coping with difficult situations. Acquiring new skills, despite fate, has a considerable impact on survival [18].

It should be noted that hospitalised persons who are covered with the programme of treatment and rehabilitation of spinal pain and spinal muscle pain also experience an increased level of anxiety [19, 20].

There is compatibility of opinions that the reaction to trauma is facilitated if the person has positive social contact [21]. The conducted research proves that the diagnosis should also cover the nature of support, because the experienced trauma may also concern the closest social environment of the participant of war actions [2]. That is why it seems justified to implement complex medical and psychological aid and a widelyunderstood rehabilitation in order to prevent the increase of anger [22].

From the social point of view, it is a valuable form of acting against the secondary increase of problems connected with experiencing difficulties connected with health, effects of experienced post-traumatic stress, and externalising fear.

The results of the research form an introduction to deeper analyses, based on the strategies, programmes, and support groups for patients (and their families) who have taken part in military actions. They will be continued in a larger group of hospitalised patients. We hope that they will constitute information that is useful in planning treatment and rehabilitation of the persons participating in military actions.

\section{Conclusions}

The conducted analysis indicates that frequently in the examined group the phenomenon of multiple morbidities takes place, even among soldiers below 25 years of age. There is a weak correlation between the value of an index of the registered systolic blood pressure of the hospitalised participants of military actions and the manifestation of anger, revealed in showing tendencies towards revengeful behaviours $(r=0.41, p<0.05)$. Based on the obtained data, we cannot say that the differentiation of externalised anger correlates with the recognition (diagnosis).

\section{Conflict of interest}

The authors declare no conflict of interest. 


\section{References}

1. Irving LM, Telfer L, Blake DD. Hope, coping, and social support in combat-related posttraumatic stress disorder. J Trauma Stress 1997; 10: 465-479.

2. Bryant RA, Harvey AG, Guthrie RM, Moulds ML. A prospective study of psychophysiological arousal, acute stress disorder, and posttraumatic stress disorder. J Abnorm Psychol 2000; 109: 341-344.

3. Buss AH. The psychology of agression. John Wiley and Sons, New York 1961.

4. Barton KA, Blanchard EB, Hickling EJ. Antecedents and consequences of acute stress disorder among motor vehicle accident victims. Behav Res Ther 1996; 34: 805-813.

5. Eme R. Neurobehavioral outcomes of mild traumatic brain injury: a mini review. Brain Sci 2017; 7: 46.

6. Feldengut $\mathrm{S}$, Del Tredici K, Braak H. Paraffin sections of 70-100 mum: a novel technique and its benefits for studying the nervous system. J Neurosci Methods 2013; 215: 241-244.

7. Gibson S. Social Psychology, War and Peace: Towards a Critical Discursive Peace Psychology. Social and Personality Psychology Compass 2011; 5: 239-250.

8. Andriychuk O, Masikova T, Ortenburger D, Ismailov R. Features of the vegetative regulation of demobabilized battle participants. Phys Educ Sports Health Cult Mod Soc 2018; 4: 68-72.

9. Jasinski MJ, Lumley MA, Latsch DV, Schuster E, Kinner E, Burns JW. Assessing anger expression: construct validity of three emotion expression-related measures. J Pers Assess 2016; 98: 640-648.

10. Juczyński Z. Narzędzia pomiaru w psychologii zdrowia. Pracownia Testów Psychologicznych Polskiego Towarzystwa Psychologicznego, Warsaw 2009.

11. McCubbin JA, Merritt MM, Sollers JJ, Evans MK, Zonderman AB, Lane RD, Thayer JF. Cardiovascular-emotional dampening: the relationship between blood pressure and recognition of emotion. Psychosom Med 2011; 73: 743-750.

12. Rossi EL. Hipnoterapia. Psychobiologiczne mechanizmy uzdrawiania. Zysk i S-ka, Poznan 2005.

13. Feinstein A. Posttraumatic stress disorder: a descriptive study supporting DSM-III-R criteria. Am J Psychiatry 1989; 146: 665-666.

14. Iversen AC, Neil Greenberg N. Mental health of regular and reserve military veterans. Adv Psychiatr Treatment 2009; 15: 100-106.

15. Ortenburger D, Rodziewicz-Gruhn J, Wasik J, Marfina O, Polina N. Selected problems of the relation between pain immunity and depression. Phys Activ Rev 2017; 5: 74-77.

16. Uher I, Svedova M. Long and prosperous life paradigm. Phys Activ Rev 2013; 1: 38-44.

17. Beliaieva N, Yavorovenko O, Kurylenko I, Danylenko Y, Pavlichenko H. Prychyny ta vazhkist invalidnosti v uchasnykiv antyterorystychnoi operatsii [Causes and severity of disability of the participants of anti-terrorist operation]. Biomed Biosoc Anthropol 2016; 27: 187-191.

18. Wasik J, Ortenburger D, Góra T. The kinematic effects of taekwondo strokes in various conditions the outside environment. Interpretation in the psychological aspect and perspective of application in sport, health-related training and survival abilities. Arch Budo 2016; 12: 287-292.

19. Bener A, Verjee M, Dafeeah EE, Falah O, Al-Juhaishi T, Schlogl J, Sedeeq A, Khan S. Psychological factors: anxie- ty, depression, and somatization symptoms in low back pain patients. J Pain Research 2013; 6: 95-101.

20. Szerla M, Ortenburger D, Wyszomierska J, Kluszczynski M. Exercise and psychological factors in low back pain. Phys Activ Rev 2017; 5: 11-14.

21. Izaute M, Durozard C, Aldigier E, Teissedre F, Perreve A, Gerbaud L. Perceived social support and locus of control after a traumatic brain injury (TBI). Brain Inj 2008; 22: 758-764.

22. Sogabe A. Influence of difference in knee alignment on site of pain and psychological state after long-distance walking. Phys Activ Rev 2013; 1: 1-9.

\section{Address for correspondence:}

\section{Prof. Jacek Wąsik}

Faculty of Health Sciences

Jan Dlugosz University

ul. Armii Krajowej 13/15, Częstochowa, Poland

Phone: +48 503053142

E-mail: j.wasik@ajd.czest.pl 